\title{
Recontextualisation of the Second Amendment and Supreme Court Decisions IN THE NEW YorK TIMES
}

\begin{abstract}
The Second Amendment to the Constitution of the United States was written over two centuries ago, but it is yet to find a definitive interpretation. The current article aims to explore its history by investigating how it has been recontextualised in Supreme Court precedents. A related aim is to underline the historically contingent nature of discourse through focusing on the phenomenon of recontextualisation. The media representation of the three Supreme Court precedents that have dealt with the amendment, United States v. Miller, District of Columbia v. Heller and McDonald v. Chicago, is analysed. Media texts were collected from The New York Times between 2007 and 2011. The analysis looks at two articles from that period and includes the single article on the 1939 Miller decision. The results illustrate how the amendment has acquired new meanings by moving from one context to another and, thus, given rise to new texts and discourses.
\end{abstract}

Key words

Discourse analysis; recontextualisation; media discourse; the United States; Second Amendment; gun rights

\section{Introduction}

\subsection{Recontextualisation in discourse}

The concept of recontextualisation as used in Critical Discourse Analysis has been adopted from Bernstein (1996, Fairclough 2006) as a resource for "the detailed specification of time-space disembedding and re-embedding" (Chouliaraki and Fairclough 1999: 110). Bernstein (1996: 32) states that "as the discourse 
moves from its original site to its new positioning [...], a transformation takes place. The transformation takes place because every time a discourse moves from one position to another, there is space in which ideology can play." The concept of recontextualisation has been used (van Leeuwen 2008, Caldas-Coulthard 2003, Hodges 2008) to analyse the transition of text form one context to another. With this transition, recontextualisation chains are formed and these function as filters (van Leeuwen 2008, Fairclough 2005, 2006), adding or subtracting from the original discourse. These chains are instances of the same text or echoes of it appearing in related texts in different contexts over time. Thus, recontextualisation becomes a process of (selective) appropriation and colonisation (Fairclough 2006, Chouliaraki and Fairclough 1999) and a factor in social transformations which, for Fairclough (2006: 27), "are extensively 'discourse-led' in the sense that it is discourses which change first," and only then is it possible to enact, inculcate or materialise them in social practices.

As recontextualisation can lead to preferred enactments and materialisations, it is vital to investigate its effect on discourse production. In looking at the social frameworks that guide recontextualisation, Ehrlich (2007) observes that overarching cultural frames shape people's understanding of discourse on a metadiscursive level and, depending on the frames people have, lead to very different interpretations of the same situation. Ehrlich (2007) also claims that in the course of recontextualisation, initial texts are interpreted and certain interpretations by certain (authoritative) participants come to dominate, potentially forming the official interpretation of an event. In the struggle over who gets to establish these interpretations, discourse becomes a central concept, as "it is through discursive interaction that we can come to ascribe meanings" (Hodges 2008: 485). Hodges (2008: 500) concludes that by analysing recontextualisation it is possible to "gain a glimpse of the way socio-political reality is negotiated on the micro-level of social interaction."

Recontextualisation as a resource of investigating the micro-level negotiation of meaning and construction of preferred metadiscourses is a broad concept which requires specific tools for its analysis. Recontextualisation can be viewed on two levels: "on one level it is the presence in my discourse of the specific words of the other mixed with my words, as for instance in reported speech; on another level it is the combination in discourse of different genres - or, we might add, different discourses" (Chouliaraki and Fairclough 1999: 49). These are the two levels of intertextuality: manifest intertextuality (Fairclough 2003; applied, for instance, by Rahm (2006)) and constitutive intertextuality (or interdiscursivity).

Following Kristeva (1986), Fairclough (2001: 233) states that intertextuality means "the idea that any text is explicitly or implicitly 'in dialogue with' other texts (existing or anticipated) which constitute its 'intertexts'." According to Fairclough (1999: 102), intertextuality points to "the productivity of texts; to how texts can transform prior texts and restructure existing conventions [...] to generate new ones." This productivity is not available to everyone: it is socially limited and depends on power relations (Fairclough 1999). Blommaert (2005) likewise considers intertextuality inevitable in the sense that writing or saying something 
unavoidably makes use of something that has already been written or said. All utterances have histories of use and abuse which allows "expressions to acquire powerful social, cultural, and political effects" (Blommaert 2005: 46).

Blommaert (2005: 46) sees intertextuality in the fact that "whenever we speak we produce the words of others, we constantly cite and recite expressions, and recycle meanings that are already available". This results in all utterances having histories of (ab)uses which makes "occurrences of discourse [...] intrinsically historical" (Blommaert 2005: 100). Blommaert sees intertextuality as an abstract and inevitable process in the production of discourse. In order to analyse specific texts, he makes a distinction between intertextuality and entextualisation in which the latter is a process closely connected with intertextuality. Entextualisation is the natural history of textuality, that is, of how social actors lift texts from their initial contexts and change them (Silverstein and Urban 1996). Blommaert defines entextualisation as a

process by means of which discourses are successively or simultaneously decontextualised and metadiscursively recontextualised, so that they become a new discourse associated to a new context and accompanied by a particular metadiscourse which provides a sort of 'preferred reading' for the discourse. (Blommaert 2005: 47)

As a tool of analysis, entextualisation points to the specific instances of existing texts being introduced into a new one, turning "intertextuality into an empirical research programme" (Blommaert 2005: 47). Entextualisation can be seen in instances where other voices directly enter into a discourse (for example, as direct quotes in media texts). As such, it is a useful concept in the analysis of news articles, focusing on the multitude of voices and opinions and pointing to different sources included in a media text. For that, and in order to more clearly distinguish what has been termed both intertextuality and manifest intertextuality from the other type of intertextuality, interdiscursivity, the article proceeds by adopting the concept of entextualisation from Blommaert (2005) for the analysis of the direct inclusion of voices in media texts.

\subsection{Second Amendment and its history in the Supreme Court}

The Second Amendment (SA) to the Constitution of the United States (ratified in 1791) has an enigmatic wording: "A well regulated militia, being necessary to the security of a free state, the right of the people to keep and bear arms, shall not be infringed" (Woll 1990: 632). This wording resulted from the fact that at the time the SA was written, the states had varying approaches to gun rights. Many did not specify the right to bear arms, although most listed the obligation to participate in the militia (Cornell 2006). The Virginia Declaration of Rights, for example, talked about a militia, but did not specifically mention a right to bear arms; whereas Pennsylvania specified the right to bear arms without mentioning 
the militia (U.S. Constitution Online n.d.). In the end, the SA was put into words that have ever since been the confusing starting point of discussions of gun rights in the US (Winkler 2007).

The philosophical underpinnings of the right are commonly taken back to English law (Levinson 1989, Williams 2003, Winkler 2007, Doherty 2008) where the ability and willingness to protect one's rights and freedoms and being allowed to have arms for that purpose was the dividing distinction between free men and slaves (Shalhope 1982). For William Blackstone (n.d.: para. 41), author of the influential Commentaries on the Law of England (1765), this was an expression "of the natural right of resistance and self-preservation, when the sanctions of society and laws are found insufficient to restrain the violence of oppression". According to Blackstone (n.d.: para. 41, see also Winkler 2007), this right was subject to "due restrictions" not an absolute one: the right was reserved to people interested in preserving the state, that is, to "responsible citizens" (Shalhope 1982: 602-603) or "peaceable citizens" according to Samuel Adams (Cress 1984: 34, Levinson 1989: 648).

The Supreme Court (SC) of the United States, the highest court in the States, provides a check and balance on the other branches of government, including in regulating gun ownership. However, until a few years ago, the only previous precedent that specifically dealt with the SA, United States v. Miller, dated from 1939 already. Miller began in 1938 with the arrest of Jack Miller and Frank Layton for the possession of an unregistered sawed-off shotgun that was illegal under the National Firearms Act (NFA) of 1934 (Frye 2008). After the lower court decision in favour of Miller and Layton, the case was presented to the SC. In 1939, the court made a unanimous decision in which Justice McReynolds stated that "we cannot say that the Second Amendment guarantees the right to keep and bear such an instrument" (United States v. Miller 1939: para. 3), having in mind a sawed-off shotgun. Even though the case dealt narrowly with the sawed-off shotgun and involved the NFA, it has become interpreted broadly, creating a situation in which "the anti-gun lobby can claim that it permits reasonable regulation of firearms. Gun rights advocates say that it supports the right to own military style weapons" (Brown 2001: para. 22).

In the $20^{\text {th }}$ century, a number of states and cities enacted gun bans in an attempt to achieve some control over gun-related crime, but most were soon abolished (studies and polls over the years have demonstrated people's general dislike of aggressive gun control (Kopel 2007)). There were various gun regulations and policies in effect across the US with no clear opinion on the matter of the SA from the SC until the justices accepted District of Columbia v. Heller in 2007 and made the meaning of the SA newly topical. Heller concerned the handgun ban in place in Washington, D.C since 1976 which stated that no new guns would be allowed, other than the ones already registered by the residents (Kopel 2007, Winkler 2009). In 2003, the Cato Institute, a libertarian group against gun prohibition, initiated a lawsuit on behalf of a number of residents of the District. The challenge claimed that the ban was unconstitutional and restricted people's 
right to defend themselves. Among the original six plaintiffs, Richard Heller was found to have the strongest stand, having explicitly been denied the right to register a gun he had purchased and owned elsewhere. In March, 2007, the U.S. Court of Appeals for the D.C. Circuit struck down the ban, but both sides agreed that the justices should revisit the SA and issue a decision (Levy 2007) to guide lower courts nationwide.

The question whether the SA specifies an individual or collective right was answered in 2008, when the SC ruled for an individual right that cannot be denied outright. Still, the debate was long from settled, as the court created more questions than it answered (Winkler 2009, Põiklik 2011). For one, the justices stated that the individual right to keep and bear arms is not a universal one and reasonable restrictions can be established (without specifying how to accomplish this). An awkward contradiction emerged: "while forcefully declaring an individual right to keep and bear arms, the Court suggests that nearly all gun control laws currently on the books are constitutionally permissible" (Winkler 2009: 1561). It is due to such inconsistencies that Heller turned out to be a symbolic victory with little direct influence on gun laws; at the very least, questions of judicial review and the exact nature of allowed regulations remained. Soon, new challenges of gun laws across the nation appeared.

One such challenge, McDonald v. Chicago, reached the SC in 2009. It addressed one question left open: the possible incorporation of the SA (and its newly settled individual right reading) against the states. In short, the question was whether the individual right declared in Heller applied not only to the federal government but also to states under the Fourteenth Amendment. The section of the Fourteenth Amendment that reads "No State shall make or enforce any law which shall abridge the privileges or immunities of citizens of the United States; nor shall any State deprive any person of life, liberty, or property, without due process of law; nor deny to any person within its jurisdiction the equal protection of the laws" (Woll 1990: 634-635) provides two avenues ("privileges and immunities" and "due process of law") for incorporating laws against the states.

McDonald grew out of Chicago, which had one of the toughest gun laws: it also disallowed unregistered weapons while making it nearly impossible to register one (Denniston 2010). According to gun rights advocates, this made it impossible for law-abiding citizens to properly defend themselves while in no way hindering criminals (Savage 2009). After the trial court ruled in favour of the city, the case was appealed to the $7^{\text {th }}$ Circuit Court of Appeals which referred to their lack of authority in deciding the issue (Denniston 2010) and claimed to be limited by SC precedents from the $19^{\text {th }}$ century which suggested that the SA only restricted the federal government's efforts to limit the states' right to have wellregulated militias (Levy et al. 2009). This invited the SC to revisit the issue which it agreed to do in 2009 when it accepted McDonald. In June, 2010, the justices incorporated the SA against the states on the basis of the due process clause. Similarly to Heller, the Supreme Court's 5 to 4 ruling in McDonald was a symbolic victory for gun rights advocates, remaining unclear in its practical implications, 
as the court did not specify the standard by which state gun regulations should be reviewed (Scarola 2010, Winkler 2007). This means that there is uncertainty in what the decision actually means for the states in terms of regulating gun possession, which will most likely result in further challenges of existing gun laws.

\section{Results}

The three Supreme Court precedents that directly address the Second Amendment are United States v. Miller (1939), District of Columbia v. Heller (2008) and McDonald v. Chicago (2010). The analysis focuses on recontextualisation and (preferred) metadiscourses in news articles that reported the SC deliberation of the cases. For this, articles from The New York Times, a liberal-leaning daily newspaper, were collected using the search phrase 'second amendment' (a total of 28 articles from 2007-2011, including one news report on the 1939 Miller decision). The corpus consists of news articles; opinion pieces and editorials have been excluded in order to keep the focus on media texts that aim to provide a balanced coverage. Three of the articles analysed in detail below each report one SC decision after it was handed down, offering an immediate representation of the court opinions and reactions to the decisions. There are several reasons to investigate the media representation (especially news articles) of these cases and the eventual decisions:

(a) news articles are an object of study that is varied in voices and points of view, with multiple recontextualised sources and entextualised voices. Fairclough (2006: 23), proceeding from Silverstone (1999), sees "media texts as a class of texts which are specialised for moving resources for meaning-making between texts, and more abstractly between different social practices, fields, domains and scales of social life";

(b) media offers a glimpse into power hierarchies and access into public space, where some participants are better positioned to voice their opinions, thus, greatly influencing whether and which preferred readings are established as the "official interpretation";

(c) the $\mathrm{SC}$ as an institution is removed from the people. Although people can visit the hearings as journalists frequently do, cameras, for instance, are not allowed in the court room (and the justices conduct most of their deliberation behind closed doors). This means that their work is mediated for the majority of people.

\subsection{Right connected to the militia}

The news report on the United States v. Miller decision (The New York Times 1939) is a brief text (the only full article found in The New York Times archives next to brief statements of the fact that the SC discussed the case) that focuses 
on the narrow legal question debated in Miller (whether Miller and Layton had the right to own a sawed-off shotgun under the SA). The article is divided into 7 short paragraphs that include 5 instances of entextualisation in the form of direct quotes, two related to the SA, two to the $\mathrm{SC}$ and one to the government.

The SA, which served as the basis for Miller and Layton's challenge of the NFA, is entextualised in two instances:

(1) Sawed-off shotguns have not the slightest relation to the constitutional right of the American people to "keep and bear arms," as part of a "well regulated militia," the Supreme Court unanimously asserted today in an opinion by Justice McReynolds upholding the validity of the registration sections of the National Firearms Act.

(2) Attorneys for the two men contended that the registration clauses violated the Second Amendment of the Constitution reading: "A well regulated militia, being necessary to the security of a free State, the right of the people to keep and bear arms, shall not be infringed."

Section 1 recontextualises the SA within the limited framework of the case by segmenting it and constructing a new sentence around the segments, whereas 2 cites the amendment entirely (this is almost invariably done in articles reporting on SA cases). Legal discourse is also introduced through quotes from Justice McReynolds' verbal statement:

(3) But today Justice McReynolds drawled from the bench: "We construe the amendment as having relation to military service and we are unable to say that a sawed-off shotgun has any relation to the militia."

and from the court's written opinion:

(4) And in his written opinion, he said: "Certainly is it not within judicial notice that this weapon is any part of the ordinary military equipment or that its use could contribute to the common defense."

In this instance, the unanimous decision is cast as McReynolds's opinion which glosses over the fact that there were seven other justices involved in making the decision - a fact that plays a significant role in the other precedents.

Following the section that cites the court opinion, the article continues to connect the discussion of gun rights with the militia and gun control. It states that "Government officials felt, today, however, that the McReynolds decision had given them a new instrument with which to fight bank robbers, gangsters and other criminals, whose favourite arm is the sawed-off shotgun." Thus, the decision is firmly connected to the right to own a certain type of weapon and the amendment is cast as the basis on which such decisions can be made. This is because the case 
concerned criminals and illegal weapons - a context which greatly shaped the discourse space of the 1939 article. In other words, the preferred metadiscursive recontextualisation of the decision and the SA focus on gun control and are based on the militia clause in the amendment. The discussion of constitutional rights is less relevant than that of fighting criminals and illegal weapons; a result of the fact that the concern (dominant discourse) in the society at the time was limiting criminals' access to weapons.

\subsection{Right of the individual}

The District of Columbia v. Heller decision was expected to be "the highestprofile case on the Court's docket" (Gura 2007: para. 7). The New York Times published an article on it the day after the decision was announced on June 26, 2008 (Greenhouse 2008). The article is approximately six times the length of the 1939 article, dealing in detail with the court case and the justices' deliberation. It includes numerous entextualisations that are attributable to various participants. Compared to the Miller article, it is more difficult to separate the individual instances as the same source is often worked into several (consecutive) paragraphs and done so in a fragmented manner.

The full SA is entextualised once in connection to Justice John Paul Stevens opposing the majority opinion:

(5) Justice Stevens said the majority opinion was based on "a strained and unpersuasive reading" of the text of the Second Amendment, which provides: A well regulated militia, being necessary to the security of a free state, the right of the people to keep and bear arms, shall not be infringed.

In another instance, the SA is integrated into the text in fragments:

(6) The court rejected the view that the Second Amendment's "right of the people to keep and bear arms" applied to gun ownership only in connection with service in the "well regulated militia" to which the amendment refers.

Here, the SA is entextualised within a specific metadiscourse: it is set in the context of the Supreme Court (or at least the majority) rejecting part of it as the defining element in its application and, instead, deciding to proceed with the individual reading of the right.

The decision made is considered remarkable in the court's history and "most important in his 22 years on the court" for Justice Scalia who wrote the majority opinion. The article allows Justice Scalia to position himself and the majority as the guardians of the SA, keeping the sacred text alive despite attempts to prioritise contemporary concerns over the spread of guns (a portion of the majority opinion is entextualised: "the enshrinement of constitutional rights necessarily takes certain policy choices off the table /.../ It is not the role of this court to pro- 
nounce the Second Amendment extinct"). In doing this, however, the majority arrives at an uneasy compromise as they still accept that this right has limitations:

(7) "Nothing in our opinion,:" [Scalia] [...] said, "should be taken to cast doubt on longstanding prohibitions on the possession of firearms by felons and the mentally ill, or laws forbidding the carrying of firearms in sensitive places such as schools and government buildings, or laws imposing conditions and qualifications on the commercial sale of arms."

The opinion also said prohibitions on carrying concealed weapons would be upheld and suggested somewhat less explicitly that the right to personal possession did not apply to "dangerous and unusual weapons" that are not typically used for self-defense or recreation.

The decision is placed into a metadiscourse that expresses doubts about the clarity of the opinion; a doubt decidedly not present in the Miller article. Another difference is the entextualisation of the minority opinion. The unanimous Miller decision gave no cause for this, but this representation makes extensive use of the minority opinion as a point of contrast to the majority:

(8) Justice John Paul Stevens took vigorous issue with Justice Scalia's assertion that it was the Second Amendment that had enshrined the individual right to own a gun. Rather, it was "today's law-changing decision" that bestowed the right and created "a dramatic upheaval in the law"

The minority opinion is primarily reported as contesting the Heller departure from what the SA has traditionally been read to mean (especially after Miller).

Next to the SA and the justices' opinions, there are participants from the political realm. President Bush and his administration welcome the decision in a statement that is shortly entextualised. The article also cites the candidates of the 2008 presidential campaign, John McCain and Barack Obama. The article terms McCain's opinion a "more full-throated support" whereas Obama offered "a more guarded statement." This difference falls in line with the ideological division between Democrats and Republicans on gun rights: the latter are historically more outspoken supporters of individual gun rights. The candidates are removed from deciding the scope of the SA but, as people running for the most influential office in the US, their views on the topical matter of gun rights interest the public and are included in the media representation of the court case and of gun rights.

The Heller decision drew considerable attention from the media and the public. The decision was welcomed by gun rights advocates and criticised by gun control supporters. The report on the decision in The New York Times focuses on the opposition within the court with additional voices being included from the administration and the then presidential candidates. The article clearly conveys doubts about the decision made and points to ideological divisions inside the court and in the political realm more broadly. 


\subsection{Right of the individual on the state level}

The news article on McDonald v. Chicago by Adam Liptak was published a day after the decision was announced. It is two thirds of the length of the 2008 article and atypical among the articles from 2007-2011 as it does not specifically entextualise the SA nor include a lengthy discussion of what it might have meant for its authors or should mean today. The SA is mentioned in a context where it is already interpreted to have a specific and settled scope:

(9) The Second Amendment's guarantee of an individual right to bear arms applies to state and local gun control laws, the Supreme Court ruled Monday in a 5-to-4 decision. (emphasis added)

The article covers the majority decision and the dissent to it. The decision was made 5 to 4; with Justice Samuel Alito writing the majority opinion. Differently from the Miller and Heller articles, this article reports the fact that there were further divisions among the justices both inside the majority and minority (the justices in the majority agreed on the end result but differed on the best reasoning to arrive there). This is one of the reasons why the Fourteenth Amendment, the basis of incorporating the SA against the states, is more strongly represented in the article, as it is namely the application of its sections that the majority disagreed on. The Fourteenth Amendment is entextualised in a fragmented manner:

(10) They argued that the court should rely not on the due process clause but on the 14th Amendment's "privileges or immunities" clause, which says that "no state shall make or enforce any law which shall abridge the privileges or immunities of citizens of the United States."

The 'they' who suggest what the justices should do are constitutional scholars whose presence in the article is a new development compared to the two previous articles (the Heller article made a reference to Robert Levy, a lawyer and senior fellow at the Cato Institute, but no constitutional scholars were cited). The scholars mentioned are not identified beyond the references "many constitutional scholars" and "they" and their opinions are not specifically quoted. This marginalises their opinion as no detailed entextualisations can be attributed to any specific individual or group. Thus, the scholars do appear in the discourse space and seem to have some right to comment on what the SC should do but are left anonymous in the metadiscourse of the article.

Another source of authority is previous precedent, but instead of Miller that was cited when Heller was reported, this article makes references to Heller as the precedent that is closest in history and, more importantly, serves as the direct motivation for McDonald:

(11) The ruling came almost exactly two years after the court first ruled that the 
Second Amendment protects an individual right to own guns in District of Columbia v. Heller, another 5-to-4 decision.

But the Heller case addressed only federal laws; it left open the question of whether Second Amendment rights protect gun owners from overreaching by state and local governments.

The article positions McDonald in a direct relationship with Heller, also commenting on how the court was then similarly divided into two opposing sides. The second paragraph in 10 states that Heller created a situation in which new challenges were likely. This means that McDonald is the aftermath of Heller but, disappointingly for many interested parties, it remained almost as vague as $\mathrm{Hel}-$ ler:

(12) The ruling is an enormous symbolic victory for supporters of gun rights, but its short-term practical effect is unclear. As in the Heller decision, the justices left for another day just what kinds of gun control laws can be reconciled with Second Amendment protection. The majority said little more than that there is a right to keep handguns in the home for self-defense.

This is a source of frustration for the single representative of the political realm in the article - Richard Daley, Mayor of Chicago, who voices his opinion in a fully entextualised section and in a fragment included into the metadiscourse of the article. Differently from the 2008 election year, the presidential candidates are no longer present nor is President Obama sought out for commentary.

The metadiscourse established inevitably provides commentary for the court decision and its implications and this commentary contextualises the decision as something inadequate in settling the concerns left after Heller. This impression is strengthened by the inclusion of the voices of constitutional scholars in opposition to the majority opinion. The article allots considerable space to outlining the divisions inside the court, entextualising the divisive majority and minority opinions. With the added disapproval from the Mayor of Chicago, the preferred metadiscourse set up is one of dissatisfaction and, also, one that constructs the court as engulfed in an ideological battle rather than providing sufficient judicial guidelines.

\section{Discussion}

The SA has an interesting history in terms of the discursive construction of its meaning and application. On the one hand, the complications in its continuous interpretation have been connected to its wording, on the other, to its previous interpretations and applications. The present paper has traced its representation in The New York Times in the context of three Supreme Court precedents and has focused on the notion of recontextualisation in discourse. 
The Miller decision of 1939 was made in a time when the question of the meaning and scope of the SA was not challenged, yet within the recontextualisation chain forming the history of the SA, the Miller case has caused confusion due to being somewhat open-ended: Miller and Layton could have pursued the issue in an attempt to show that a sawed-off shotgun actually had something to do with militia service, but never did so (neither actually appeared before the $\mathrm{SC}$ and Miller was killed before he could continue with the legal process even if he had wished to). The court decision has been interpreted to support both gun rights and gun control advocates, thus, resisting the establishment of a preferred metadiscourse. The Miller article is a straightforward report in which the SA is entextualised in a manner that has little to do with debating its philosophical underpinnings or its application on different government levels. Thus, the article is strongly oriented towards the social concerns of the day through which the case and its media representation are filtered.

The Heller decision of 2008 is strongly informed and influenced by the confusion created by Miller with time being an additional factor: the fact that Miller was decided 70 years ago increasingly created a need for an up-to-date interpretation of the SA (a point also made in The New York Times article). It is apparent from the majority opinion that the justices continue to worry about public safety, as they did in 1939, and still allow for reasonable regulations. However, this no longer has specifically to do with the militia and the decision establishes the individual right as the correct reading of the SA. The Heller article sees extensive treatment of both the majority and minority opinions in which the justices (and The New York Times) focus on the linguistic and historical meaning and scope of the SA. The justices also discuss the meaning and relevance of Miller which the article mentions as the existing precedent (without specifically quoting it).

Much of the difference between Heller and Miller has to do with the different question that Heller presented to the SC, making it impossible to sidestep the question of the meaning of the amendment. In terms of preferred metadiscourses, the justices who prefer the individual reading outnumber those in favour of the collective reading. This becomes part of the judicial history of the SA and is reported as such in the article. After Heller, it would be impossible to proceed without making references to it, one reason for this being that its practical implications were left unspecified which made new challenges of gun laws almost certain (by January, 2009 Winkler (2009) accounts over 75 such cases that were decided by lower federal courts with none striking down a gun law on the grounds of Heller). This gave direct rise to the next SC case: McDonald v. Chicago which is, thus, not only an instance in which the SA and previous court precedents are recontextualised. Instead, its very existence is based on Heller, that is, it is an instance where the discourse of Heller is specifically enacted. If it had not been for the majority in Heller wanting to have an individual rights reading without sacrificing gun regulations, the McDonald challenge would have been unlikely. By the time McDonald was decided, the reading of the SA was already established. This explains why it was not specifically entextualised in the McDonald article. Instead of the SA, the 
Fourteenth Amendment is more explicitly entextualised as the basis for extending the SA and incorporating it against the states.

The three Supreme Court precedents related to the Second Amendment and their reports in The New York Times illustrate how the same text, when entextualised in different contexts, can be interpreted in very different ways; and how recontextualisation, while making use of discourse previously produced (as, for example, Heller recontextualised Miller), can also serve as a starting point for the creation of new discourse (as Heller gave rise to McDonald). Much of the difference in interpreting the SA has to do with the historical and social context of the Supreme Court precedents as well as with the ideological divisions on the court. It is the justices that have the authority to answer the questions related to the SA and, through that, prescribe enactments of discourse (that is, a new socio-political reality for lower courts and for the US as such). The ideological division on the SC was not as apparent in Miller (where the decision that criminals had no right to use a sawed-off shotgun was unanimous) as it was in Heller and McDonald. The latter decisions were made by a 5 to 4 majority which means that the result was up to a single vote on the court. This might explain why both the Heller and McDonald articles devote considerable space to detailing the divisions on the court as well as inside the majority and minority opinions. From the perspective of discourse analysis, this is a fascinating instance of authoritative participants reshaping discourse space. The history of the SA is a history of recontextualisation: from its English roots to its enigmatic wording, from its enigmatic wording to its contradictory readings and interpretations - the Second Amendment illustrates how ideology and social circumstance can affect the creation of (authoritative) discourse that will, in turn, lead to new enactments and materialisations, potentially leading to new preferred discourses that stand in opposition to the previous interpretations of the same text.

\section{References}

Bernstein, Basil (1996) Pedagogy, Symbolic Control and Identity. Theory, Research, Critique. Lanham: Rowman \& Littlefield Publishers, Inc.

Blackstone, William. (N.d.[1765]) Commentaries on the Law of England. Available at http://www. lonang.com/exlibris/blackstone/bla-101.htm, accessed June 22, 2011.

Blommaert, Jan (2005) Discourse. A Critical Introduction. Cambridge: Cambridge University Press.

Brown, Michael S. (2001). The Strange Case of United States v. Miller. Available at http://www. enterstageright.com/archive/articles/0801/0801usvmiller.htm, accessed February 16, 2008.

Caldas-Coulthard, Carmen Rosa (2003) "Cross-cultural Representation of 'Otherness' in Media Discourse." In: Weiss, Gilbert and Ruth Wodak (eds.) Critical Discourse Analysis. Theory and Interdisciplinarity. Hampshire and New York: Palgrave, 272-296.

Chouliaraki, Lilie and Norman Fairclough (1999) Discourse in Late Modernity. Rethinking Critical Discourse Analysis. Edinburgh: Edinburgh University Press.

Cornell, Saul (2006) Well-regulated Militia: The Founding Fathers and the Origin of Gun Control in America. New York: Oxford University Press.

Cress, Lawrence Delbert (1984) "An Armed Community: The Origins and Meaning of the Right to Bear Arms." The Journal of American History 71 (1), 22-42. 
Denniston, Lyle (2010) “Second Amendment Drama: Act II." Available at http://www.scotusblog. com/?p=16704, accessed April 23, 2011.

District of Columbia v. Heller (2008) District of Columbia et al., Petitioners v. Dick Anthony Heller. 554 U.S. (2008) Available at http://www.supremecourt.gov/opinions/07pdf/07-290.pdf, accessed February 12, 2009.

Doherty, Brian (2008) Gun Control on Trial. Inside the Supreme Court Battle over the Second Amendment. Washington, D.C.: CATO Institute.

Ehrlich, Susan (2007) "Legal Discourses and the Cultural Intelligibility of Gendered Meanings." Journal of Sociolinguistics, 11 (4), 452-477.

Fairclough, Norman (1999) Discourse and Social Change. Oxford: Blackwell.

Fairclough, Norman (2001) "The Discourse of New Labour: Critical Discourse Analysis." In: Wetherell, Margaret, Stephanie Taylor and Simeon J. Yates (eds.) Discourse as Data. A Guide for Analysis. London: Sage Publications.

Fairclough, Norman (2003) Analysing Discourse: Textual Analysis for Social Research. London: Routledge.

Fairclough, Norman (2005) "Critical Discourse Analysis in Transdisciplinary Research." In: Wodak, Ruth and Paul Chilton (eds.) A New Agenda in (Critical) Discourse Analysis. Theory, Methodology and Interdisciplinarity. Amsterdam and Philadelphia: John Benjamins Publishing Company, 53-70.

Fairclough, Norman (2006) "Semiosis, Ideology and Mediation: A Dialectical View." In: Lassen, Inger, Jeanne Strunck and Torben Vestergaard (eds.) Mediating Ideology in Text and Image: Ten Critical Studies. Philadelphia: John Benjamins Publishing Company, 19-35.

Frye, Brian L. (2008) "The peculiar story of United States v. Miller." NYU Journal of Law \& Liberty 3 (1), 48-82.

Greenhouse, Linda (2008) “Justices, Ruling 5-4, Endorse Personal Right to Own Gun.” Available at http://query.nytimes.com/gst/fullpage.html?res=9904E2DD1431F934A15755C0A96E9C8B6 $3 \& \mathrm{scp}=30 \& \mathrm{sq}=\% 22$ second + amendment $\% 22 \& \mathrm{st}=$ nyt, accessed April 1, 2009.

Gura, Alan (2007) "Supreme Court Agrees to Hear Second Amendment Challenge to D.C. Gun Ban." Available at http://dcguncase.com/blog/, accessed February 17, 2008.

Hodges, Adam (2008) "The Politics of Recontextualisation: Discursive Competition over Claims of Iranian Involvement in Iraq." Discourse \& Society 19 (4), 483-505.

Kopel, David (2007) “Gun Prohibitionists Mostly Misfire.” Available at http://www.cato.org/pub_ display.php?pub_id=8807, accessed 16 February, 2008.

Kristeva, Julia (1986) “Word, Dialogue and Novel.” In: Moi, Toril (ed.) The Kristeva Reader. New York: Columbia University Press, 34-61.

Levinson, Sanford (1989) “The Embarrassing Second Amendment." The Yale Law Journal 99 (3), 637-659.

Levy, Robert A. (2007) “The D.C. Gun Ban: Supreme Court Preview.” Available at http://www. cato.org/pub display.php?pub id=8717, accessed February 17, 2008.

Levy, Robert A, Ilya Shapiro and Roger Pilon (2009) "National Rifle Association v. City of Chicago; McDonald v. City of Chicago." Cato Institute, July 6. Available at http://www.cato.org/ pub_display.php?pub_id=10336, accessed June 8, 2011.

Liptak, Adam (2010) "Justices Extend Firearm Rights in 5-to-4 Ruling." The New York Times, June 29. Available at http://www.nytimes.com/2010/06/29/us/29scotus.html?r=1\&scp=2\&sq=second $\% 20$ amendment\&st $=$ cse, accessed July 22, 2010.

McDonald v. Chicago (2010) Otis McDonald, et al., Petitioners v. City of Chicago, Illinois, et al. 561 U.S. (2010). Available at http://www.supremecourt.gov/opinions/09pdf/08-1521.pdf, accessed January 13, 2011.

Põiklik, Pille (2011) "The Unalienable Right to Keep and Bear Arms? Interpreting the Second Amendment to the United States Constitution in the Light of American Ideals." Estonian Journal of English Studies 2 (1), 110-124.

Rahm, Henrik (2006) "Getting attention in the media." In: Lassen, Inger, Jeanne Strunck and Tor- 
ben Vestergaard (eds.) Mediating Ideology in Text and Image: Ten Critical Studies. Philadelphia: John Benjamins Publishing Company, 193-210.

Savage, David (with Kristen Schorsch contributing) (2009) "Supreme Court to hear challenge to Chicago gun law." Chicago Breaking News Centre, September 30. Available at http://archive. chicagobreakingnews.com/2009/09/supreme-court-may-decide-on-hearing-chicago-gun-cases. $\mathrm{html}$, accessed November 12, 2010.

Scarola, Matthew (2010) “Analysis: state gun regulations and McDonald." Available at http://www. scotusblog.com/?p=22475, accessed 22 May, 2011.

Shalhope, Robert E. (1982) "The Ideological Origins of the Second Amendment." The Journal of American History 69 (3), 599-614.

Silverstein, Michael and Greg Urban (1996) "The Natural History of Discourse.” In: Silverstein, Michael and Greg Urban (eds.) Natural Histories of Discourse. Chicago and London: The University of Chicago Press, 1-17.

Silverstone, Roger (1999) Why Study the Media? London: Sage Publications.

The New York Times (1939) "Supreme Court Bars Sawed-Off Shotgun. Denies Constitution Gives Right to Carry This Weapon." The New York Times, May 16.

United States v. Miller (1939) 307 U.S. 174. Available at http://usgovinfo.about.com/library/bills/ blusvmiller.htm, accessed January 12, 2010.

U.S. Constitution Online (N.d.) "Constitutional Topic: The Second Amendment." Available at http://www.usconstitution.net/consttop_2nd.html, accessed August 1, 2010.

van Leeuwen, Theo (2008) Discourse and Practice. New Tools for Critical Discourse Analysis. Oxford: Oxford University Press.

Williams, David C. (2003) Mythic Meanings of the Second Amendment : Taming Political Violence in a Constitutional Republic. New Haven: Yale University Press.

Winkler, Adam (2007) "Scrutinizing the Second Amendment." Michigan Law Review 105 (4), 683-733.

Winkler, Adam (2009) "Heller's Catch 22." UCLA Law Review 56, 1550-1577.

Woll, Peter (1990) American Government. Readings and Cases. 10 ${ }^{\text {th }}$ edition. New York: Harper Collins.

Pille PõIKLIK is a doctoral student and assistant lecturer at the Institute of Germanic, Romance and Slavonic Languages and Literatures at the University of Tartu, Estonia where she teaches practical English and analytical reading. Her research interests include Critical Discourse Analysis, positioning and space in discourse, media discourse and American studies. Her doctoral thesis Positioning Social Actors in Discourse: The Socio-political Role of the Supreme Court of the United States in Constitutional Debates is focused on the analysis of the media representation of the Supreme Court discussion of gun rights in the United States. Pille is part of the research group Multimodal Communication Research at the University of Tartu.

Address: Department of English Language and Literature, Ülikooli 18, Tartu 50090, Estonia. [email: pille.poiklik@ut.ee] 
